\title{
GOMMENTARIES
}

\section{TREATY INTERPRETATION: A COMMENT}

\section{ABraham D. Sofaer $\dagger$}

The key question in the treaty interpretation "debate" is: what standards are correct for judging whether the President is bound to an interpretation of a treaty under domestic law because of the manner in which the treaty was presented to the Senate? Professor Koplow's analysis of the treaty interpretation issue is more accurate than that of most of the prior critics of the Reagan Administration's views on this subject. Like so many of the Administration's critics, however, Professor Koplow misstates my position and that of the Administration on some issues, particularly on the straw man called the "Sofaer doctrine." The alleged "Sofaer doctrine" is no more than a polemical device, utilized in a political controversy, and has never had any basis in fact. I realize that disputes between the political branches will not always be fought by Roberts' Rules. I take responsibility, in fact, for any misunderstandings that might have existed on the part of certain Senators. But I cannot accept Professor Koplow's reliance on the "Sofaer Doctrine," as he purports to present a scholar's account. He should have limited his criticisms to those areas in which we truly hold different positions, rather than exploiting a politically generated mischaracterization of my position. ${ }^{1}$ It is, however, apparent that Professor Koplow has conceded

† Legal Adviser, United States Department of State. This comment draws in part upon my luncheon address to the American Law Institute on May 19, 1988, reprinted in AMERICAN Law InSTITUTE, Remarks and AdDResses at THE 65TH ANNUAL MEETING, MAY 17-20, 1988, at 23 (1989).

I Professor Koplow shows at several points that he was aware of my true position, for example, when he refers to my letter in Time which answered Senator Biden's claims. He even agrees with and restates my position, flatly asserting exactly the same proposition. See Koplow, Constitutional Bait and Switch: Executive Reinterpretation of Arms Control Treaties, 137 U. PA. L. REv. 1353, 1374 (1989). Nonetheless he allows the impression to be conveyed that the Senators had a proper basis for their interpretation of my statement, for example in the quotation out of context in id. at n.224.

Similarly, Judge Greene clearly misrepresented the position of the Department of State in a hearing on the Rainbow Navigation case, as referenced in id, at 1399. Judge Greene made this statement even though my study had long been published, and it was clear that this was not the position of the Department of State or the United States 
most aspects of my position on treaty interpretation. On the issues where we differ, I remain comfortable with the views I espoused during the ABM Treaty debate.

To begin with, it is important to realize how far the terms of this debate over treaty interpretation have moved toward the Administration's position in the last two years. When the controversy began in March 1987, Senator Nunn argued that, as a matter of our international obligations under the ABM Treaty, the United States had a "very strong basis in law" for insisting on the interpretation of a treaty as presented to the Senate during advice-and-consent proceedings, whatever the United States and Soviet Union may have said to each other prior to ratification. ${ }^{2}$ Many taking part in the debate before the joint sessions of the Senate Foreign Relations and Judiciary Committees in 1987 jumped on the bandwagon Senator Nunn had started and adopted similar positions. ${ }^{3}$ Some found the capacity to accuse me, in all seriousness, of having the nerve to claim that a treaty is negotiated between the United States and a foreign nation, rather than between the President and Senate. ${ }^{4}$

I said then, and repeat now, that a treaty is an international agreement between nations, and is governed by international law. The Restatement (Third) of Foreign Relations Law explicitly recognizes this fact. The Senate is a branch of the United States Government, and must act effectively under international law standards to affect the meaning under international law of any treaty it considers. Under international law, statements made during internal ratification proceedings (and not formally communicated to a treaty partner prior to ratification) cannot alter the obligations which that party actually assumed under the treaty negotiated. ${ }^{5}$ The Senate's power to affect the meaning

government. Indeed, the government agreed with Judge Greene that executive statements can be binding; the only question was whether they were binding in the specific instance before the court. See Navigation, Inc. v. Department of Navy, 699 F. Supp. 339,343 \& n.16 (D.D.C. 1988).

2 See The ABM Treaty and the Constitution: Joint Hearings before the Senate Comm. on Foreign Relations and Senate Comm. on the Judiciary, 100th Cong., 1st Sess. 59-60 (1987) [hereinafter Joint Hearings].

3 See, e.g., The ABM Treaty InTERPRetation Resolution, S. Rep. No. 164, 100th Cong., 1st Sess. 57 (1987) [hereinafter BIDEN Commitree RePoRT] (testimony of Lawrence H. Tribe); id. at 59 (view of the Committee); see also Joint Hearings, supra note 2, at 415 (prepared statement of Lawrence H. Tribe).

4 Professor Lawrence $H$. Tribe rejected what he called "the Legal Adviser's Model." He understood this model to stand for the proposition that "the meaning of the ABM Treaty is to be gleaned not by examination of what the President and the Senate agreed upon, but by examination of what the President and the Soviets agree upon-regardless of what the President may or may not have told the Senate about what he had negotiated." BIDEN COMMITTEE REPORT, supra note 3, at 57.

s Restatement (Third) of Foreign Relations Law $\S 313$ comment d 
of a treaty under international law is to "exclude, limit or modify" treaty obligations through a formal reservation, or to give "its advice and consent to a treaty on the basis of a particular understanding of its meaning ... ." The President must make the treaty on the basis of that reservation or understanding by communicating the reservation or understanding to the treaty partner prior to ratification. The treaty partner is then free to accept or reject the treaty with that reservation or understanding; a failure to object to an understanding is strong evidence that the understanding is mutual. ${ }^{7}$ Most critics of the Administration appear to have come around to this view of the law. The Senate Foreign Relations Committee's report on the INF Treaty ${ }^{8}$ and Professor Koplow, to his credit, recognize that Executive representations to the Senate cannot themselves create obligations for a treaty party to which it did not agree prior to ratification.

This is an important point. Other nations are very unlikely to accept the proposition that statements not formally communicated to them prior to ratification have any binding effect on them with respect to a treaty's meaning. In fact, both the United States ${ }^{9}$ and the Soviet Union $^{10}$ have rejected this proposition, the latter in a formal bilateral

(1987) [hereinafter RESTATEMENT] (describing the following procedure in the case of multilateral agreements: "A reservation, an express acceptance of a reservation, or an objection to a reservation, must be formulated in writing and communicated to the contracting states and other states entitled to become parties to the agreement."); id. at $\$ 314(1)$ (noting that if the Senate gives advice and consent to a treaty on condition that the United States enters a reservation, the President must include the reservation in the instrument of ratification, "or otherwise manifest that the adherence of the United States is subject to the reservation"); STAFF of SENATE CoMm. ON FOREIGN Relations, 95Th Cong., 1st Sess., The Role of the Senate in Treaty RatifiCation: Staff Memorandum to the Senate Foreign Relations Committee 13 (Comm. Print 1977) [hereinafter SFRG STAFF REPORT].

- Restatement, supra note $5, \S 314(2)$.

7 Vienna Convention on the Law of Treaties, opened for signature May 23, 1969, Art. 2(d), reprinted in 63 AM. J. INT'L L. 875, 876 (1969) (definition of "reservation"); RESTATEMENT, supra note 5 , at $\S 313$ comments $\mathrm{f}, \mathrm{g} ; \mathrm{id}$. at $\S 314$ comments b, d.

8 The INF Treaty, S. Rep. No. 15, 100th Cong., 2d Sess. 99-100 (April 14, 1988) [hereinafter INF TREATY REPORT].

- Secretary of State Hughes to Ambassador Houghton, July 30, 1923, reprinted in 5 G. HACKWORTH, Digest OF INTERnational LAw 262 (1943) ("expressions of meaning" of a treaty "occurring in general debate, cannot be regarded as affecting the interpretation of that treaty"); SFRC STAFF REPORT, supra note 5, at 13.

${ }_{10}$ In 1981, the United States Delegate to certain bilateral talks referred to a statement relating to the interpretation of the ABM Treaty, made by Ambassador Smith to the Senate during the ratification hearings, on a point different than "other physical principles" systems. The United States Delegate noted that the Soviets had never objected to Ambassador Smith's interpretation. The Soviet participant replied that Smith's statement was an internal matter and that the sides were bound by the letter of the agreement and not by one side's interpretation. OFFICE OF THE LEGAL ADVISER, THE ABM Treaty Studies, Part II: Ratification Process 41 (May 11, 1987) [here- 
exchange concerning the ABM Treaty. In light of the principle of reciprocity, moreover, we could not credibly assert that our internal proceedings on advice and consent have binding effect without conceding the same for the internal proceedings of other states. Such a result would clearly be contrary to our interests, and would produce a chaotic situation for treaty interpretation.

The Administration has also recognized, however, from the outset of this debate, that the Senate may adopt particular understandings of a treaty that are not formally communicated to the treaty partner. When the Senate acts in this manner, while it cannot change the meaning of the treaty under international law, its understandings may be effective in binding the President under domestic law.

I testified to this effect at the hearings during March and April 1987 conducted jointly by the Senate Foreign Relations and Judiciary Committees. On the one hand, I disagreed with the view of some Senators that the United States could rely on its internal proceedings to bind the Soviet Union to an understanding of the treaty that could not be established under international law. On this issue, I said: "When [the Senate] gives its advice and consent to a treaty, it is to the treaty that was made, irrespective of the explanations [the Senate] was provided." On the other hand, and in the same testimony, I also made clear our view that the President could not disregard Executive representations to the Senate, and that such representations could bind him under domestic law to a particular meaning of the treaty or course of conduct, if the Senate accepts and relies on them. I said, for example, that "the President cannot, and should not, disregard views expressed in Senate proceedings ... ." I noted Secretary of State Shultz's statement that, while what is said during the ratification process in the United States is important to the Executive Branch, "that has absolutely no standing as far as the Soviets are concerned." I said: "That is the point that we are making here today - 'insofar as the Soviets are concerned.' We do believe that such statements have standing insofar as the Senate is concerned and insofar as our relationship with the Senate is concerned." My memorandum on the ABM treaty negotiating record, I told the Committees, "is not addressed to any duties created by the entire ratification process for the President to the U.S. Senate. So, the President cannot and will not and does not disregard those statements."11

The parts of my testimony confirming the President's duty to consider and, at times, to be bound by Executive Branch representations to

inafter ABM Treaty Study Part II] (summarizing classified Memorandum of Conversation presented to the Senate).

11 Joint Hearings, supra note 2, at 128-129. 
the Senate were systematically disregarded in the heat of the ABM debate. Some Senators focused exclusively on the part of my testimony dealing with international law, and claimed I had taken the position that the President could disregard Executive branch representations to the Senate. In fact, these claims continued after my office's study on the Senate's consideration of the ABM Treaty was published on May 11, 1987. That study spelled out in detail our view that the President could be bound by Executive representations, including the standards by which we believe such judgments should be made. It also included numerous examples of informal Senate understandings treated as binding by the Executive. ${ }^{12}$

The Reagan Administration's position on this issue, as on the others in the ABM Treaty debate, was based upon the principles expressed in the Restatement (Third) of Foreign Relations Law. The Restatement recognizes the possibility that the Senate might reach an understanding of a treaty, even though that understanding has not been communicated to the treaty partner. In that event, while the understanding cannot be relied upon to alter the treaty's meaning among or between the countries involved, the Restatement concludes that the "treaty that is ratified or acceded to by the United States with a statement of understanding becomes effective in domestic law . . . subject to that understanding." If a formal statement of the Senate's understanding is made, then the Senate's position is clearly on record. Where no such statement is made, however, the technique to be applied in ascertaining the President's or the Senate's understanding is to look at all the indications of such an understanding "in much the same way that the legislative history of a statute is relevant to its interpretation." The Restatement notes, moreover, some of the possible sources of such "indications" of an informal understanding, including the Senate's resolution of consent, "the report of the Senate Foreign Relations Committee," and "the Senate debates."13

12 See ABM TREATy StUdy PART II, supra note 10, at 50-55.

13 Restatement, supra note $5, \S 314$ comment d (emphasis added, citation omitted). These issues were recently touched upon in an inconclusive manner by the Supreme Court in United States v. Stuart, 109 S. Ct. 1183 (1989). In dicta, Justice Brennan suggested that a treaty's ratification record was a better source for treaty interpretation than the negotiating history, because of its character as a public record. Id. at 1191-92 \& n.7. Justice Scalia objected to this dicta in a concurring opinion, arguing that the use of ratification record materials was inappropriate, not only because the treaty before the Court was clear on its face, but also because the ratification record represented only an internal, unilateral proceeding and not the mutual understandings of the parties. Id. at 1195 (Scalia, J., concurring). This exchange gives little indication of how the Court would hold if the issue were squarely before it, since the issue was clearly peripheral to the decision and was evidently not briefed or argued by the parties. 
The Restatement also offers a specific legal standard to govern situations in which an informal understanding should be given binding weight. The Restatement provides that "the President must decide whether [the indications of an informal understanding in the Senate record] represent a general understanding by the Senate, and, if he finds that they do, he must respect them in good faith."14 Finally, it is essential to remember that the understanding involved not only must be generally held by the Senate, but must be an understanding "on the basis" of which the Senate gave its advice and consent. ${ }^{16}$ The Restatement does not require the President to defer to understandings on which the Senate could not be said to have conditioned its approval of the treaty. This is entirely consistent with the notion that a treaty's history should be analyzed in much the same way legislative history is analyzed.

These were the standards applied in my office's study of the Senate record of advice and consent to the ABM Treaty. We concluded, and it is irrefutable, that the Senate record contains no formal or informal "statement of understanding" that indicates the Senate gave its advice and consent "on the basis of" the "restrictive interpretation" of the ABM Treaty. We did find "indications" in the record - in Executive testimony and statements of Senators - that support the restrictive interpretation, along with indications that cast doubt upon that interpretation, or support a broader interpretation. My study concluded that these indications, taken in the context of the record as a whole, were insufficient to establish a duty to respect the restrictive interpretation under domestic law, but were sufficient to require the President to decide, in accordance with the Restatement, whether "they represent a general understanding by the Senate" of the restrictive interpretation. If he found that they did, he "must respect them in good faith."16 I strongly believe that the Legal Adviser should not preclude the President from exercising the power to decide issues of this sort. In less contentious contexts, I have no doubt that the Senate, and scholars such as Professor Koplow, would readily acquiesce to the view that a Senate record, such as the one developed for the ABM Treaty, is not binding as a matter of law. The issue was briefly addressed by the Senate and was unlikely to have affected the outcome (the vote on advice and consent was 88 to 2 ).

Here, as on the other issues in the ABM Treaty debate, the differ-

14 Restatement, supra note 5, $\S 314$ comment d (emphasis added).

15 Id. at $\S 314(2)$.

${ }^{16} I d$. at $\S 314$. For the discussion of the ratification record, see ABM TREATY STUDY PART II, supra note 10 , at 55-59. 
ences between the Administration and its opponents have narrowed substantially, though on this issue some differences do remain. Over time, most critics have come to the view that the weight to be accorded any Executive Branch representation depends upon its clarity and authority. Executive Branch representations, moreover, are but one source in determining what the Senate may or may not have understood and intended at the time of ratification, and are not necessarily dispositive on these issues. ${ }^{17}$

The Senate Foreign Relations Committee's report on the INF Treaty substantially modified the approach of the Biden Committee. The Foreign Relations Committee proposed a "rule of reason" in which all relevant factors are taken into account when weighing the significance of Executive testimony. The report states that:

[A] rule of reason must apply. Gertainly, substantial weight must be accorded the Executive formal presentation documents ... . Considerable weight must also be accorded the prepared testimony of top Executive officials. Additional information elicited during Executive-Senate interaction regarding the meaning and legal effect of treaty terms will also be important because such discussion and questioning will convey items of particular interest and concern to the Senate $\ldots$. $^{18}$

This analysis went a long way toward accepting the Administration's views, though of course without suggesting any such movement. The report remained deficient in its analysis, however, by suggesting the propriety of treating the Senate's "acquiescence" in Executive statements too readily as a basis for implying an intention to bind the President. ${ }^{19}$

The central question is whether the Senate as a whole had some specific understanding and intent. Executive Branch statements are but one source of evidence, to be considered along with others, in answering that question. Professor Koplow's position is also far closer to the Administration's than he chooses to admit. He concedes that the weight to be accorded Executive Branch statements depends on the character of the representations and the surrounding circumstances. In his words, "clear, consistent and voluminous" statements by "high-ranking and knowledgeable" Executive witnesses, as well as the Secretary of State's

17 See Restatement, supra note 5, $\S 314$ comment d; SFRC STAFF REPORT, supra note 5 , at $12-13$.

${ }^{18}$ INF TREATY REPORT, supra note 8, at 98.

10 See id. at 101, 103, 107-08. 
official section-by-section analysis and other written communications to the Senate, can "reasonably be deemed to have had a substantial impact upon the legislators' understanding", and therefore have "special weight." On the other hand, if Executive witnesses were "relatively junior, or relatively uninformed," or if they were giving "impromptu oral responses to spontaneous questions," or if the issue was covered "only sparingly and obliquely," then it is easier to argue that they "did not create a common Senate understanding."

Professor Koplow's article repeats a criticism of the Administration's position that had been voiced by the Senate Foreign Relations Committee; the standards of the so-called "Sofaer Doctrine" for determining when an informal Senate understanding is binding are "so stiff that they may only rarely be met." ${ }^{21} \mathrm{He}$ was, in this instance, referring to the following statement in a March 1988 letter from White House Counsel A.B. Culvahouse: "As a matter of domestic law, however, the President is bound by shared interpretations which were both authoritatively communicated to the Senate by the Executive and clearly intended, generally understood, and relied upon by the Senate in its advice and consent to ratification."22

Recognizing that legitimate differences may exist over the precise words used in this particular formulation, these concepts seem unobjectionable in principle. All now seem to agree that only "authoritative" Executive representations have weight. Koplow himself stresses the need to determine whether the Senate had a "collective understanding" or a "considered view" or an "expression on point" with respect to a proposed treaty interpretation, whether there was a "congressional directive" or a "legislative consensus" on the matter, and whether particular senatorial statements "purport[] to be binding." 23 The Senate's INF Treaty condition itself refers to "the understanding of the Treaty shared by the Executive and the Senate."24

Legislative intent, understanding, and reliance are standard concepts in statutory interpretation and are regularly applied by United States courts and administrative agencies. Contrary to Koplow's base-

20 See Koplow, supra note 1, at 1421-22.

${ }^{21} \mathrm{Id}$. at 1418.

${ }^{22}$ Letter from White House Counsel Arthur B. Culvahouse to Senator Richard Lugar, reprinted in INF TREATY REPORT, supra note 8, at 443, 444.

${ }^{23}$ See Koplow, supra note 1, at 1402, 1406 \& n.217.

24134 Cong. Rec. S6937 (daily ed. May, 27 1988). Senator Nunn expressly accepted the standards in the Culvahouse letter, though in Senator Specter's words, he later "disavowed" that position during the INF ratification floor debate. 134 CoNG. REC. S6778-79 (daily ed. May 26, 1988). 
less claim, ${ }^{26}$ each of the three standards is supported by practice and precedent. The requirement that the understanding be "generally understood" was derived from the Restatement rule in section 314 , comment $d$, which provides that the President must decide whether indications in the Senate record "represent a general understanding by the Senate."28 This requirement makes sense, especially because both the Restatement and my study apply it reasonably. Both treat indicia, such as a reference in a Senate committee report, as a general understanding. ${ }^{27}$ The requirement that the understanding be "relied upon" by the Senate stems from the rule in section $314(2)$. That rule requires the President to make a treaty consistent with any particular understanding "on the basis of" which the Senate gives its advice and consent. ${ }^{28}$ This rule should not be used to require a showing that the Senate would have acted differently but for the understanding. But the Restatement rule - and good sense - requires that the matter be one of sufficient significance so that an inference of the Senate's reliance upon it can reasonably be drawn.

The final requirement is that the understanding be "clearly intended" as a limitation on the Executive. This requirement stems from the methodology the Restatement explicitly states should be utilized in ascertaining the existence of a particular understanding in the absence of a clear condition or statement. Whether such an understanding exists should be determined "in much the same way that the legislative history of a statute is relevant to its interpretation." 29 My study examined the leading precedents for determining when Congress intends in a statute to limit the Executive to a particular understanding. I rely on cases that are neither cited nor discussed by Koplow. ${ }^{30}$ These cases fully support the requirement of proof of a legislative intention to limit the President to a particular understanding. For legislative history to prevent the President from adopting a construction that is otherwise reasonable, the record as a whole must reflect a positive legislative determination to adopt a different interpretation.

${ }^{25}$ In making this claim, Professor Koplow cites the Biden Committee Report for his support, even though he has read the Legal Adviser's study and knows that it contain extensive analysis and citation of authorities. $\mathrm{He}$ also cites, as though it were authority, a New York Times editorial that called the standards we proposed "mumbo jumbo," Koplow, supra note 1, at 1419. Professor Koplow should have dealt with the cases and authorities actually relied on in our study.

${ }^{28}$ Restatement, supra note 5, § 314 comment d.

27 See id.; ABM TREATY STUdy PART II, supra note 10, at 55-59.

28 See RestatemENT, supra note 5, § 314(2).

29 Id. $\S 314$ comment d.

so See ABM Treaty Study Part II, supra note 10, at 48-49. 
In the Japanese Whaling Association case, ${ }^{31}$ the Court required deference to the Executive's construction of a statute "unless the legislative history of the enactment shows with sufficient clarity that the agency construction is contrary to the will of Congress."32 Where no such express intent is found, subsequent agency interpretation - including reinterpretation - is generally accorded appropriate deference and held to a general standard of reasonableness. In Cheoron, U.S.A. v. Natural Resources Defense Council, ${ }^{33}$ the Court upheld a reinterpretation which an agency adopted after "a new administration took office and initiated a 'Government-wide reexamination of regulatory burdens and complexities." "s4 These cases are ignored by Koplow, as they were in the Biden committee and INF Treaty reports. ${ }^{35}$ The law in fact gives substantial leeway to the President to reinterpret statutes, and his special authority and function in foreign and military affairs strongly supports the application of no less flexible a rule with regard to treaties.

Nor is it the Administration's intention to interpret these concepts in such a way that they would "rarely" be met, short of a formal Senate condition on its advice and consent. In my ABM study I cited a number of past examples in which informal Senate understanding embodied in committee reports, correspondence with the Executive Branch, and colloquies on the Senate floor were treated as binding. ${ }^{36}$ This process is neither mysterious, nor "rare," nor "impossible;" Congress has never found it difficult to express its intent in this fashion.

Professor Koplow criticizes the Administration's criteria as being

31 Japan Whaling Ass'n v. American Cetacean Soc'y, 478 U.S. 221 (1986).

32 Id. at 233.

3s 467 U.S. 837 (1984).

s4 $I d$. at $857-58$ (citation omitted).

so Professor Koplow's position in this regard reflects a determined preconception by him-similar to that held by others-that the law could not conceivably support my view (and therefore leave open the possibility of the President's implementing the broad interpretation). This was taken to its logical extreme when the Senate majority voted to reject an amendment to the INF resolution that simply recognized the supremacy of domestic and international law as interpreted by the Supreme Court:

Notwithstanding any provision in the Resolution of Ratification, or the Biden Condition as amended by the Byrd Condition, or any statement in the Senate Foreign Relations Committee Report on the INF Treaty, there is no intent by the Senate to change the heretofore accepted constitutional law of the United States on treaty ratification as interpreted by Supreme Court of the United States or the heretofore accepted international law on treaties as interpreted by Supreme Court of the United States.

134 Cong. Rec. S6890 (daily ed. May 27, 1988). This proposed amendment to the resolution was defeated 64 to 33. Id. at S6893-94.

${ }^{36}$ See ABM TREaTy Study ParT II, supra note 10, at 50-55. The precedents cited by Koplow are consistent with this analysis. 
unclear, and says that uncertainty will exist in particular cases as to what the Senate's intent or understanding may have been. In their place, however, he suggests a list of eight factors, none of which is dispositive by itself, and all of which require subjective judgments about the circumstances and what they indicate as to the Senate's intent. ${ }^{37}$ Neither his eight factors, nor the Administration's three standards, nor the Senate's INF Treaty condition, nor any other formula will provide clear, objective answers to all situations likely to arise. A considerable element of judgment will always have to be exercised, and when such issues evoke intense feelings they will be resolved through the political process, rather than by application of neat legal criteria.

I suspect that what Professor Koplow and other critics of the Administration are saying is not so much directed at our criteria, as at the fact that these criteria establish a reasonable basis for the position that the broad interpretation of the ABM Treaty could justifiably be adopted and implemented by the President without the Senate's approval. The only prerequisite for such adoption is the President's considered conclusion that he could do so in good faith without violating a general understanding of the Senate.

The specific question of the interpretation of the ABM Treaty is, of course, a matter on which reasonable men may differ and have differed. ${ }^{38}$ Professor Koplow's view on this point is not clear: he sets scenarios for the various models of "reinterpretation," but never says which model applies to the ABM Treaty. That question, however, is separate from the question of what criteria should be used to judge treaty interpretation. In fact, Presidential implementation of the broad interpretation of the ABM Treaty seems equally justifiable under Koplow's eight factors as under the three we utilized. His failure to apply the criteria he advances to the record on advice and consent of the $\mathrm{ABM}$ Treaty is a curious omission, though not surprising to those who believe that the record is far more ambiguous than fervent advocates of

37 See Koplow, supra note 1, at 1418-25.

38 In discussing the ABM Treaty dispute, Koplow notes that most of the ABM negotiators support the restrictive interpretation. He fails to note, however, that Paul Nitze, one of the key ABM negotiators, has supported the broader interpretation throughout this controversy. Indeed, Professor Koplow's treatment gives the impression that the broad interpretation is supported only by me, when it is actually supported by key officials for the period in which the ABM Treaty was negotiated and ratified (including National Security Adviser Henry Kissinger and Chairman of the Joint Chiefs of Staff Moorer), and was supported by the agency chiefs consulted by President Reagan for their opinions on the issue. The negotiating record's most reliable elements-the formal drafts of the parties as compared to the Treaty as finally adopted-strongly indicate that the Soviets never agreed to the restrictive interpretation as advanced by the U.S. negotiators. See generally, Sofaer, The ABM Treaty: Legal Analysis in the Political Cauldron, WASH. Q. 59 (Autumn 1987). 
the restrictive interpretation would have liked. Professor Koplow's criteria would also be denounced as manipulations designed to serve purely political ends once they were shown to enable the President to adopt the broad interpretation.

Some of the tests upon which Professor Koplow's thesis ultimately stands have no basis in law, though they may make eminently good sense from the viewpoint of policy. He says, for example, that once an interpretation becomes "entrenched" it cannot be altered by unilateral action, and he postulates a "principle of durability" under which we are informed that "[t]he Executive's attempt to reinterpret established aspects of a treaty is an unconstitutional usurpation of power."39 While I fully agree a President should act only in good faith, and should as a matter of policy avoid changing established and accepted norms, the law leaves at least some room for a President to take a different view than taken in the past, even if it is a view that must be cleared with the Senate. Furthermore, the restrictive interpretation became "entrenched" only in 1978, when Paul Warnke, then director of the Arms Control Disarmament Agency, began submitting that interpretation to Congress in reports on ballistic missile defense, and then only domestically (it was first accepted by the Soviet Union in 1985). ${ }^{\mathbf{4 0}}$

Professor Koplow's article appears to criticize the Administration for pointing out the importance of avoiding the imposition on domestic law of any interpretation more restrictive than that which would govern under international law. He says that this concern is misplaced because treaties often provide asymmetrical rights and duties for the parties. ${ }^{41}$ This is true, but beside the point. While it may be proper to negotiate asymmetrical provisions when appropriate and consistent with United States interests, when a treaty provision imposes the same obligation on both parties it is obviously undesirable (even though possible) for the Senate to impose a stricter interpretation on the United States than that which we can enforce against the other party under

s9 See Koplow, supra note 1, at 1357.

40 Compare United States Arms Control \& Disarmament Agency, Arms Control and Disarmament AgreEments 132 (1975) and United States ARmS Control \& Disarmament Agency, Arms Gontrol and Disarmament AgreeMENTS 131 (1977) (only stating obligation to discuss OPP systems) with UNITED States ARms Control \& Disarmament Agency, Fiscal Year 1979 ARms ConTROL IMPACT STATEMENT 231 (1979) (affirmatively stating that fixed, land-based OPP systems, and no others, could be developed); see also OfFICE OF THE LEGAL Adviser, The ABM Treaty Studies Part III: Subsequent Practice 44-55 (1987); id. at 96 (summarizing U.S.-Soviet bilateral discussions, including Soviet assertions as to meaning of the ABM treaty). Mr. Warnke is also the Chairman of the Committee for which Professor Koplow submitted his report.

${ }^{41}$ See Koplow, supra note 1, at 1408-12. 
international law. Professor Koplow could not seriously mean to suggest that it would be consistent with United States interests to allow the Soviets to govern their SDI program by the broad interpretation while the United States program is governed by the restrictive view.

Finally, Professor Koplow wildly exaggerates when characterizing the ABM Treaty dispute as a "new constitutional crisis" that "has been a threat to gut the central purposes of the ABM Treaty and to abort the nascent INF Treaty [which could] in the longer term, undermine United States arms control policies, jeopardize future Strategic Arms Reduction Talks ("START") agreements, and weaken the security of the international community." ${ }^{42}$ None of these dire events has happened or is likely to happen. The President and the Congress are dealing with the ABM issue through the political process as is proper and, in any event, inevitable. Professor Koplow has simply followed a pattern established by some Senators of misstating and overdramatizing these issues in order to substitute rhetoric for reason in their attacks.

In fact, no crisis has at any time existed. President Reagan never decided whether he could in good faith implement the broad interpretation without the Senate's prior consent, or whether he would even attempt to do so. Indeed, before the INF Treaty debate, the President signalled his realization that he could not act alone; he agreed to a law that prevented him from conducting, without prior Congressional approval, tests that were justifiable under the broad interpretation.

During the Senate's consideration of the INF Treaty, both the Administration and the Senate acted cooperatively to resolve questions about the interpretation of the Treaty. In response to Senate requests, the Administration supplied the entire negotiating record to the Senate on a classified basis, gave a very full account of the negotiation and meaning of the Treaty, and provided numerous detailed answers (orally and in writing) to questions by Senators. ${ }^{43}$

For its part, the Senate carried out its constitutional responsibilities in a serious and thorough manner. On a series of issues where Senators found potential ambiguity, they obtained detailed Executive responses, examined the relevant negotiating history to confirm for themselves what the parties to the treaty had actually agreed, and in a

42 Id. at $1452-53$.

43 See e.g., Letter from Secretary of State Shultz to Senators Byrd and Dole, February 5, 1988 (on file at University of Pennsylvania Law Review) (supplying negotiating history with terms of reference); Message from the President of the United States Transmitting the Treaty between the United States of America and the Union of Soviet Socialist Republics on the Elimination of Their Intermediate-Range and ShorterRange Missiles to the Senate, 100th Cong., 2d Sess. VII-XVI, 1-69 (1988) (giving background and article-by-article analysis). 
few cases required the Executive to go back to the Soviets for clarification. The Senate did not, as Professor Koplow suggests, rely on any supposed binding effect of Executive representations; they determined for themselves whether the Treaty and its negotiating history adequately established the correctness of Administration positions.

By performing in this manner, the Senate was playing its proper role in our constitutional process. It demeans that role to suggest that the Senate should simply accept all Executive representations, however authoritative, as the dispositive and legally binding meaning of a treaty, irrespective of the treaty's true meaning as agreed between the parties, and irrespective of whether the Senate understood and relied on those representations. The Senate, in short, should participate as a partner in ascertaining the true meaning of a treaty and shape it as necessary through proper means. The nation's interests are not served when the need for mutuality of obligation is subordinated to the Senate's claim to the right to control the President through domestic law limitations not binding on treaty partners. 